\title{
Genetic diversity of locally adapted sheep from Pantanal region of Mato Grosso do Sul
}

\author{
B.A. Crispim ${ }^{1}$, A.B. Grisolia ${ }^{1}$, L.O. Seno ${ }^{2}$, A.A. Egito $^{3}$, F.M. Vargas Junior ${ }^{2}$ \\ and M.R. Souza ${ }^{2}$ \\ ${ }^{1}$ Faculdade de Ciências Biológicas e Ambientais da Universidade Federal da \\ Grande Dourados, Dourados, MS, Brasil \\ ${ }^{2}$ Faculdade de Ciências Agrárias da Universidade Federal da Grande Dourados, \\ Dourados, MS, Brasil \\ ${ }^{3}$ Embrapa Gado de Corte, Campo Grande, MS, Brasil \\ Corresponding author: B.A. Crispim \\ E-mail: brunocrispim.bio@gmail.com
}

Genet. Mol. Res. 12 (4): 5458-5466 (2013)

Received August 26, 2013

Accepted October 18, 2013

Published November 11, 2013

DOI http://dx.doi.org/10.4238/2013.November.11.7

\begin{abstract}
Sheep of the Pantaneiro breed and seven other breeds, raised in the State of Mato Grosso do Sul, Brazil, were genotyped using eight microsatellite loci. The aim of the present study was to determine the genetic variability, phylogenetic relationship, and patterns of gene introgression and miscegenation among the animals surveyed, to obtain information about the genetic structure of locally adapted sheep in Mato Grosso do Sul. A total of 195 animals were used for genetic analysis. The Pantaneiro breed had the largest average number of alleles/locus (9.25), and higher allelic richness (6.95), while the Dorper population had the lowest values for these parameters (4.88 and 3.86, respectively). Analysis of genetic distance values and genetic structure between populations made it possible to characterize these animals with regard to distinct genetic groups. Average expected heterozygosity ranged from 0.72 (Pantaneiro) to 0.55 (Dorper), while average observed heterozygosity ranged from 0.63 (White Dorper) to 0.54 (Dorper). On the basis of the statistical parameters evaluated, it
\end{abstract}


was possible to demonstrate that when compared to other populations, the Pantaneiro breed represented a reservoir of genetic diversity with rare and useful alleles for genetic improvement, emphasizing the importance of preserving the breed.

Key words: Genetic resources; Pantaneiro sheep; Genetic variability

\section{INTRODUCTION}

The sheep industry in the State of Mato Grosso do Sul is expanding, and the locally adapted breed (Gomes et al., 2007) known as Pantaneiro sheep (OPT), may be useful for increasing the production chain, since it is highly adapted to the environmental conditions of the region and can be used for rustic genetic material.

In 2007, an exploratory study conducted by researchers from the Universidade ANHANGUERA - UNIDERP, Universidade Federal da Grande Dourados (UFGD), Empresa Brasileira de Pesquisa Agropecuária (EMBRAPA), and Universidade Federal do Mato Grosso do Sul (UFMS) was initiated, aimed at identifying and conserving the OPT breed found in different locations in the state. Initially the researchers involved acquired about 450 animals, including ewes and rams, from different herds found in the Pantanal region of Mato Grosso do Sul, in regions including Anastácio, Nioaque, Aquidauna, and Pedro Gomes.

The OPT breed has a combination of alleles of wool sheep breeds from the southern region of Brazil and woolless breeds from the northeast region of the country. This fact shows the possibility that these animals may constitute a distinct genetic group (Gomes et al., 2007). The females of these animals have high maternal ability and no reproductive seasonality. Lambs have high productive potential in terms of carcass traits and meat quality. Furthermore, the OPTs provide wool, used in regional craftwork, as a by-product. Currently, OPT is most often found on isolated farms in the region, and lives for years without any kind of artificial selection or genetic improvement, suggesting that these sheep are locally adapted to the region (Vargas Junior et al., 2011).

In general, multilocus molecular genetic markers such as microsatellites are suitable for studies of both genetic variability and paternity tests. In addition, microsatellites provide genome-wide coverage, and are easy to detect. Microsatellites are codominant, highly polymorphic, and have an expected heterozygosity that is commonly greater than 0.7 , allowing discrimination between individuals (Regitano and Coutinho, 2001).

Molecular analyses may support both identification of areas of priority for genetic resource conservation programs, and knowledge about the genetic diversity of endangered domestic and wild species (Rosa and Paiva, 2009). Therefore, the establishment of conservation programs using molecular tools is of fundamental importance for the generation of information regarding the genetic diversity patterns of locally adapted groups, allowing them to be used in the productive system, and adding traits of adaptation and rusticity (Barker, 1994).

Research that evaluates genetic variability is of great importance to the generation of information that allows OPT to be characterized. Therefore, the aim of this study was to determine genetic diversity, patterns of gene introgression and occurrence of miscegenation among OPT and other breeds of sheep raised in the State of Mato Grosso do Sul. 


\section{MATERIAL AND METHODS}

\section{Animals}

Blood samples from 195 animals from seven populations of sheep, raised in the State of Mato Grosso do Sul, Brazil, were collected randomly from different herds. The collection sites and number of animals sampled are described in Table 1.

Table 1. Data relative to the population, sampling sites and number of animals.

\begin{tabular}{lcl}
\hline Population & Sample size & Locality \\
\hline Bergamácia & 30 & Retiro dos Leite - Jardim/MS \\
Pantaneiro & 30 & Fazenda Experimental UFGD - Dourados/MS \\
Dorper & 30 & Cabanha Morena - Caarapó/MS \\
White Dorper & 15 & Cabanha Morena - Caarapó/MS \\
Hampshire Down & 30 & Fazenda Mate Laranjeira - Ponta Porã/MS \\
Suffolk & 30 & Cabanha LCL - Caarapó/MS \\
Ile de France & 30 & Fazenda Chancan - Campo Grande/MS \\
\hline
\end{tabular}

MS = Mato Grosso do Sul.

\section{Microsatellite loci}

Total genomic DNA was extracted from blood tissue using the organic method described by Sambrook et al. (1989) and adapted by Crispim et al. (2012).

PCR were performed using a commercially available panel of eight microsatellite loci as previously described by Souza et al. (2012) (CSRD247, HSC, OarAE129, MAF214, OarFCB304, OarCP49, SPS113, and D5S2). The reactions were performed using a multiplex fluorescent system, with the eight markers included in the same reaction. The PCR were performed in a final volume of $10 \mu \mathrm{L}$, containing: $3.6 \mu \mathrm{L}$ ultrapure water, $1.5 \mu \mathrm{L} 10 \mathrm{X}$ PCR buffer, $1.5 \mu \mathrm{L}$ mix of primers, $50 \mathrm{mM} \mathrm{MgCl}, 10 \mathrm{mM}$ dNTPs, $0.4 \mu \mathrm{L}$ Platinum ${ }^{\circledR}$ Taq DNA Polymerase (Invitrogen) and 3.0 $\mu \mathrm{L}$ DNA (50-100 ng). The reactions were then placed in a thermocycler (Applied Biosystems).

The thermocycling program consisted of an initial denaturation step at $95^{\circ} \mathrm{C}$ for 7 min, followed by 40 cycles at $95^{\circ} \mathrm{C}$ for $30 \mathrm{~s}$, annealing at $63^{\circ} \mathrm{C}$ for $90 \mathrm{~s}$ and extension at $72^{\circ} \mathrm{C}$ for $60 \mathrm{~s}$. A final extension step at $72^{\circ} \mathrm{C}$ for 30 min was performed at the end of the 40 cycles.

After PCR, the amplified products were electrophoresed in a MegaBACE ${ }^{\mathrm{TM}} 1000$ DNA Analysis System (GE Healthcare, USA). Accordingly, a solution with TWEEN and molecular weight marker ET-400 (GE Healthcare) was prepared. A total of $0.3 \mu \mathrm{L}$ ROX marker, $7.7 \mu \mathrm{L}$ 0.02X TWEEN and $2 \mu \mathrm{L}$ amplified product were added. The samples were denatured for $3 \mathrm{~min}$ at $94^{\circ} \mathrm{C}$ and placed directly on ice. Sample injection was performed at $3 \mathrm{kV}$ for $80 \mathrm{~s}$ and the electrophoretic run performed at $8 \mathrm{kV}$ for $80 \mathrm{~min}$. Genotyping results for allele discrimination were visualized in the Fragment Profiler program version $1.2^{\circledR}$ (GE Healthcare).

\section{Statistical analysis}

Allele frequency was estimated by direct counting. The parameters of locus diversity were 
estimated for all microsatellites, in all populations, using the CERVUS 3.0 program (Kalinowski et al., 2007). The parameters were as follows: expected $\left(H_{\mathrm{E}}\right)$ and observed heterozygosities $\left(H_{\mathrm{O}}\right)$, polymorphic information content, and the Hardy-Weinberg Equilibrium (HWE). The FSTAT program was used to calculate allelic richness $(\mathrm{AR})$ and estimates of Wright's F statistics $\left(F_{\mathrm{IT}}\right.$, $F_{\text {IS }}$ and $F_{\text {ST }}$ ). The $\mathrm{P}$ value was adjusted using the Bonferroni procedure (Goudet, 2002) with the same statistical package. Population structures were evaluated by analysis of molecular variance (AMOVA) using the ARLEQUIN program (Schneider et al., 2000).

The dendrogram was constructed by cluster analysis using the Neighbor-Net method with the aid of the Sliptree program, based on calculations of Reynold's genetic distances $\left(F_{\mathrm{ST}}\right)$ using FSTAT.

On the basis of allelic frequency of the eight microsatellite loci, the animals were grouped in a given number of populations and probabilistically placed into groups inferred by Bayesian analysis using the Structure program (Pritchard et al., 2000). The tests were performed using an admixture model where the allelic frequencies were correlated. To select the appropriate number of inferred populations, several analyses were conducted with $\mathrm{K}$ (number of populations inferred) ranging from 2 to 10, with 300,000 interactions (burn-in period of 3000 ), with three independent replications for each analysis. The real values of $\mathrm{K}$ were inferred from the magnitude of $\Delta \mathrm{K}$ and given as a function of $\mathrm{K}$, with the aid of the Structure Harvester program (Earl and vonHoldt, 2012) following the model proposed by Evanno et al. (2005).

\section{RESULTS}

The genetic parameters observed from the genotyping of the 195 animals of the seven populations analyzed with eight microsatellite loci are described in Table 2. OPT breed showed the highest number of alleles per locus (9.25), and the highest allelic richness (6.95) compared to the other populations of animals in the present study. The Dorper population showed the lowest values (4.88 and 3.86, respectively).

When all the populations were analyzed together, the microsatellite loci HSC, CSRD247 and OarAE129 were found to be in HWE. However, when statistical analysis was performed for each population, White Dorper animals had no markers in HWE. The Pantaneiro breed and Bergamácia and Hampshire Down populations had the highest number of markers in HWE. In relation to other populations, Ile de France showed two loci and the Dorper population only one locus in HWE (Table 2).

Table 2. Estimates of genetic variability observed in the seven populations studied based on eight microsatellite loci.

\begin{tabular}{|c|c|c|c|c|c|c|c|}
\hline \multirow[t]{2}{*}{ Populations } & \multirow[t]{2}{*}{$\mathrm{N}$} & \multirow[t]{2}{*}{$N_{\mathrm{A}}$} & \multicolumn{2}{|c|}{ Heterozygosity } & \multirow[t]{2}{*}{$\mathrm{AR}$} & \multirow[t]{2}{*}{$F_{\text {IS }}$} & \multirow[t]{2}{*}{ Loci in HWE } \\
\hline & & & Observed & Expected & & & \\
\hline Pantaneiro & 30 & $9.25 \pm 3.77$ & $0.63 \pm 0.03$ & $0.72 \pm 0.04$ & 6.95 & $0.129^{*}$ & 3 \\
\hline Bergamácia & 30 & $5.75 \pm 1.67$ & $0.60 \pm 0.03$ & $0.63 \pm 0.06$ & 4.75 & 0.062 & 3 \\
\hline Dorper & 30 & $4.88 \pm 3.27$ & $0.54 \pm 0.03$ & $0.55 \pm 0.09$ & 3.86 & 0.021 & 1 \\
\hline White Dorper & 15 & $5.13 \pm 2.47$ & $0.70 \pm 0.04$ & $0.69 \pm 0.05$ & 5.06 & 0.027 & 0 \\
\hline Suffolk & 30 & $6.00 \pm 2.14$ & $0.66 \pm 0.03$ & $0.65 \pm 0.07$ & 5.05 & 0.019 & 2 \\
\hline Hampshire Down & 30 & $7.38 \pm 2.97$ & $0.68 \pm 0.03$ & $0.65 \pm 0.05$ & 5.88 & 0.045 & 3 \\
\hline Ile de France & 30 & $5.25 \pm 2.12$ & $0.60 \pm 0.03$ & $0.66 \pm 0.03$ & 4.62 & $0.079 *$ & 2 \\
\hline
\end{tabular}

$\mathrm{N}=$ number of individuals; $N_{\mathrm{A}}=$ mean number of alleles; $\mathrm{AR}=$ allelic richness; HWE $=$ number of loci that showed deviations from Hardy-Weinberg equilibrium. $* \mathrm{P}<0.05$. 
The population structure analysis revealed a genetic difference between populations of $13.72 \%$ (Table 3 ), and estimates of differentiation based on $F_{\mathrm{ST}}$ were significant $(\mathrm{P}<0.001)$.

Table 3. Analysis of molecular variance interpopulation and intrapopulation of the seven sheep populations studied.

\begin{tabular}{lrcc}
\hline Source of variation & d.f. & Variation (\%) & FI \\
\hline Interpopulation & 6 & 13.72 & $F_{\mathrm{ST}}=0.13721^{*}$ \\
Intrapopulation & 194 & 88.33 & \\
\hline
\end{tabular}

d.f. $=$ degrees of freedom; FI $=$ fixation index. $* \mathrm{P}<0.001$.

The matrix of genetic differentiation between populations, based on $F_{\mathrm{ST}}$ indices, is shown in Table 4. It can be observed that the highest rates of genetic differentiation were between the Bergamácia and Hampshire Down populations (0.250). On the other hand, the lowest values were between the Suffolk and Hampshire Down populations (0.069). Using population differentiation, it was shown that the OPT breed was genetically closest to animals in the Suffolk population (0.078).

Table 4. Pairwise estimation of genetic differentiation among the sheep populations studied.

\begin{tabular}{lccccccc}
\hline & OB & DP & DW & HS & IF & OPT & SF \\
\hline OB & - & - & - & - & - & - & - \\
DP & 0.18140 & - & - & - & - & - & - \\
DW & 0.12440 & 0.19948 & - & - & - & - & - \\
HS & 0.25082 & 0.21992 & 0.16221 & - & - & - \\
IF & 0.17938 & 0.23601 & 0.09408 & 0.13918 & - & - \\
OPT & 0.10757 & 0.10130 & 0.08177 & 0.08359 & 0.08823 & - & - \\
SF & 0.19916 & 0.24001 & 0.12801 & 0.06941 & 0.08389 & 0.07853 & - \\
\hline
\end{tabular}

$\mathrm{OB}=$ Bergamácia; $\mathrm{DP}=$ Dorper; DW = White Dorper; HS = Hampshire Down; IF = Ile de France; OPT = Pantaneiro; $\mathrm{SF}=$ Suffolk

Neighbor-Net method data analysis indicated that the OPT breed occupied an intermediate position in relation to other populations. Suffolk and Hampshire Down populations grouped differently, showing their genetic proximity when compared with other populations. The Dorper population had the greatest distance in relation to other populations (Figure 1).

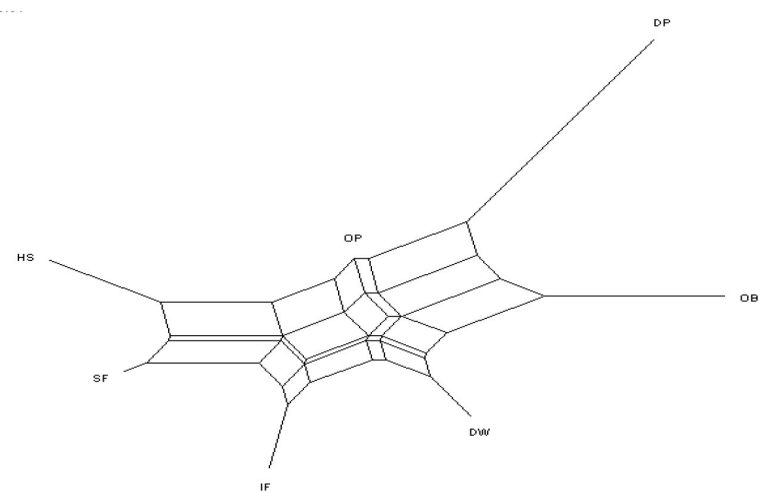

Figure 1. Neighbor-Net dendrogram based on Reynold's genetic distance $\left(F_{\mathrm{ST}}\right)$ from eight microsatellite loci. The graph show the genetic relationships between the seven sheep populations studied (OPT = Pantaneiro; DP = Dorper; $\mathrm{DW}=$ White Dorper; $\mathrm{OB}=$ Bergamácia; HS = Hampshire Down; IF = Ile de France, and SF = Suffolk). 
Table 5 shows the proportions of each population attributed to the five groups inferred by the Structure program, with minimal variance.

Table 5. Number of individuals $(\mathrm{N})$ per population and proportion of association of each population in each of the 5 groups inferred by the program Structure.

\begin{tabular}{|c|c|c|c|c|c|c|}
\hline \multirow[t]{2}{*}{ Populations } & \multirow[t]{2}{*}{$\mathrm{N}$} & \multicolumn{5}{|c|}{ Inferred clusters } \\
\hline & & 1 & 2 & 3 & 4 & 5 \\
\hline Bergamácia & 30 & 0.890 & 0.009 & 0.015 & 0.061 & 0.025 \\
\hline Dorper & 30 & 0.024 & 0.012 & 0.020 & 0.023 & 0.921 \\
\hline White Dorper & 15 & 0.514 & 0.071 & 0.052 & 0.243 & 0.120 \\
\hline Hampshire Down & 30 & 0.016 & 0.023 & 0.792 & 0.147 & 0.022 \\
\hline Ile de France & 30 & 0.012 & 0.897 & 0.026 & 0.048 & 0.017 \\
\hline Pantaneiro & 30 & 0.152 & 0.044 & 0.081 & 0.646 & 0.077 \\
\hline Suffolk & 30 & 0022 & 0.047 & 0.756 & 0.151 & 0.023 \\
\hline
\end{tabular}

Associations greater than 0.5 are in bold.

It can be seen from Table 5 that clusters 1, 2 and 5 represented the populations of Bergamácia, Ile de France and Dorper, with 89, 89.7 and 92.1\%, respectively, correct allocation of individuals in their populations. Cluster 3 represents the populations of Hampshire Down and Suffolk, with a correct allocation rate of 79.2 and $75.6 \%$, respectively. The White Dorper population showed the lowest allocation value $(51 \%$ in cluster 1$)$ with statistical significance $(\mathrm{P}>0.05)$. The highest significant attribution proportion was $64.6 \%$ in cluster 4 for the Pantaneiro group.

The genetic structure of populations was analyzed using Bayesian statistics with the aid of the Structure program. The grouping of $\mathrm{K}=5$ (Figure 2) corresponds to the real K, according to the methodology proposed by Evanno et al. (2005), where there were complex patterns of miscegenation for all populations analyzed. The diagram showed similarity between populations of Hampshire Down and Suffolk, and between the breeds Bergamácia and White Dorper. In spite of having a lower proportion than the other groups, the Bergamácia and White Dorper breeds seemed to share the same gene pool. There appeared to be miscegenation in the Pantaneiro breed.

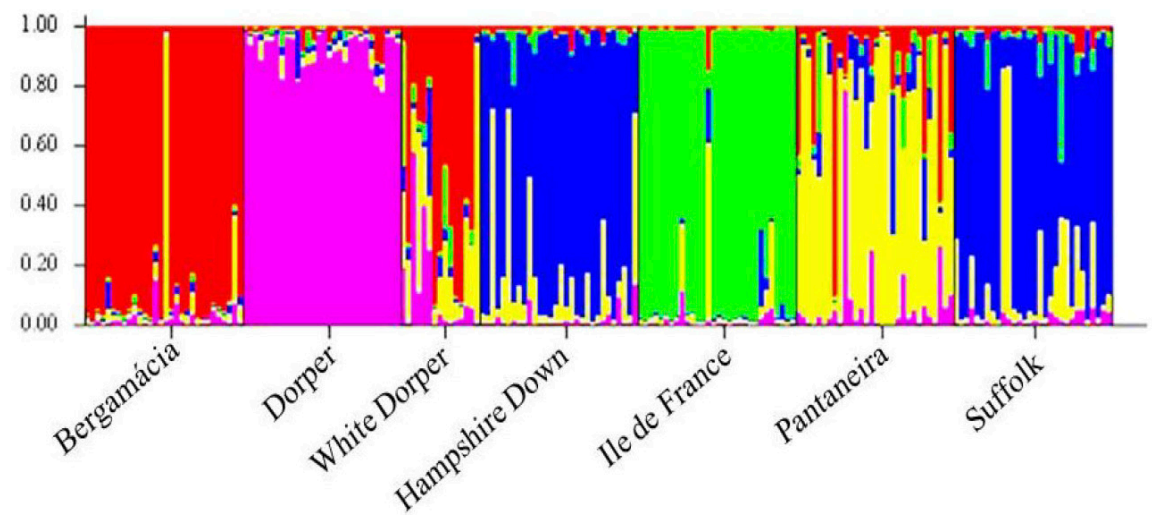

Figure 2. Individual grouping of 195 sheep from seven different populations analyzed by Bayesian statistical method using the Structure program. Each animal was represented by a vertical line divided into segments classified according to size and color, corresponding to the relative proportion of the genome of the animal concerning the population inferred by the program. Different populations were separated by black lines. 


\section{DISCUSSION}

The Pantaneiro breed showed greater allelic richness when compared with the other study populations (Table 2). The introduction of sheep in South America occurred simultaneously with colonization, and the effective population size is in the process of formation. The high levels of diversity found in the different populations studied may be related to the fact that selective pressure, coupled with miscegenation, led to the introgression of genes in the populations. However, animals in the Dorper population, which were subjected to a consolidated process of genetic improvement, showed lower allelic richness and observed heterozygosity.

The results of the present study are consistent with those observed by Gornas et al. (2011) and Álvarez et al. (2012), who also found low variability and $H_{\mathrm{O}}$ in specialized sheep breeds. Therefore, the Pantaneiro breed may constitute an important reservoir of genetic diversity, and may be useful in breeding programs and genetic management of herds.

The eight microsatellite loci were considered multi-allelic for the Pantaneiro breed (Table 2). Considering the animals genotyped, the population parameters related to average number of alleles (9.25), $H_{\mathrm{O}}(0.63), H_{\mathrm{E}}(0.72)$ and $\mathrm{AR}(6.95)$ were considerably higher when compared with results from the other populations in study. The population parameters observed in the present study were also higher than those observed in other sheep breeds, both locally adapted, and exotic, from Spain (Calvo et al., 2011), India (Arora et al., 2011), Italy (Lasagna et al., 2011), and Cuba (Álvarez et al., 2012).

Tolone et al. (2012) found very similar results when analyzing five Sicilian sheep breeds with 20 microsatellites (average of 10.95 alleles per locus for the native sheep Pinzirita). Baumung et al. (2006) reported an average of 15 alleles, when 25 microsatellite markers were genotyped in 11 Austrian breeds. Although estimates of the average number of alleles may vary according to each marker under study, it can be inferred that the genotyping method used in the present study revealed that the Pantaneiro population had relatively high levels of genetic diversity. There may be rare alleles in the current population, which can be useful in future breeding programs, if related to resistance characteristics and environmental adaptability.

The higher number of marker loci in HWE found for the Pantaneiro, Bergamácia and Hampshire Down populations may be explained by the fact that these animals are not derived from controlled crosses (breeding programs). However, the White Dorper was the only population that showed no marker in HWE. This result may be due to the small sample population (15 individuals), and due to the population being consolidated with planned genetic crosses established from breeding programs. Several studies using locally adapted or native breeds confirmed that these breeds have more number of loci in HWE when compared to more specialized breeds (McManus et al., 2010; Paiva et al., 2011a; Tolone et al., 2012).

It can be seen from the dendrogram (Figure 1) that populations with possible common ancestry were more closely related, as well as Suffolk, Hampshire Down and Ile de France. This fact can be explained by the sharing of common alleles of the same ancestor of European origin (Southdown) (ARCO, 2013), providing genetic similarity and closeness, as indicated in the graph by the Neighbor-Net method. The Pantaneiro breed was positioned medially in the graph, demonstrating that it is a locally adapted breed, which may show miscegenation with the other populations analyzed, but is genetically distinct.

AMOVA results showed that the variation between populations was high (Yeh, 2000) and significant, with fixation index $\left(F_{\mathrm{ST}}=0.13\right)$. On the basis of this criterion, it is possible 
to infer that each of the populations under study may be considered an independent genetic group. Therefore, the OPT breed may be considered different from the other populations studied, even if there is a degree of miscegenation with other breeds raised in the region (Figure 2 and Table 2).

The number of populations, as well as the population structure generated by the Structure program (Figure 2), also confirmed that the Pantaneiro breed is genetically distinct. Although there is a sharing of alleles with other populations inferred, and the number of markers used was insufficient to distinguish all breeds studied, the present study is the first to characterize the Pantaneiro breed. From the perspective of accreditation of this population as a distinct breed, the present results were very satisfactory, being consistent with the history of the populations analyzed.

The results observed in the matrix of genetic differentiation, and the analysis performed by the Structure program, indicated that Hampshire Down and Suffolk populations have a high degree of similarity (0.06). This can be explained by the formation process of the populations, determined by common ancestry, due to their similar function in the sheep industry and supposed racial admixture (Blackburn et al., 2011). In a meta-analysis performed by Paiva et al. (2011b), association among these populations was also confirmed, grouping them into the same cluster.

According to Table 5, it is possible to observe that in genetically homogeneous breeds or populations, tests for individual allocation are more effective. Possibly, better results would be obtained by increasing the number of markers, enabling the use of these tests for the composition or genetic management of populations of Pantaneiro sheep.

Selected genes over generations among groups of naturalized animals provide greater adaptive value to tropical conditions in comparison to artificially improved breeds. These genes will be useful if the climate change predicted for the coming years is considered. This research demonstrates the importance of exploiting the potential of the genetic diversity found in locally adapted herds. Although exotic breeds are considered to be of high performance, they also have reduced productivity because of their inability to properly adapt to the climatic conditions and breeding and management systems used in Brazil. The introgression of genes between these populations may generate sheep whose overall average productivity and rusticity may be greater than those of their parents.

The seven sheep populations studied may be considered genetically distinct. The breed showed higher genetic variability when compared to the other groups studied. This fact indicates the importance of conserving the Pantaneiro breed, which may possess rare alleles that are economically important to the genetic improvement of sheep.

\section{ACKNOWLEDGMENTS}

Research supported by FUNDECT, UFGD and CAPES. The authors are also grateful to the veterinary inspector Elton Bock Corrêa (Brazilian Association of Sheep Breeders) and to Dr. Raquel Soares Juliano (Embrapa Pantanal).

\section{REFERENCES}

ARCO (2013). Assistência ao Rebanho de Criadores de Ovinos. Associação Brasileira de Criadores de Ovinos. Available at [http://www.arcoovinos.com.br]. Accessed January 10, 2013. 
Arora R, Bhatia S, Mishra BP and Joshi BK (2011). Population structure in Indian sheep ascertained using microsatellite information. Anim. Genet. 42: 242-250.

Álvarez I, Capote J, Traoré A, Fonseca N, et al. (2012). Genetic relationships of the Cuban hair sheep inferred from microsatellite polymorphism. Small Rumin. Res. 104: 89-93.

Barker JSF (1994). A Global Protocol for Determining Genetic Distances Among Domestic Livestock Breeds. In: Proceedings of the 5th World Congress on Genetics Applied to Livestock Production, Guelph and Ontario, Canada, 21: 501-508.

Baumung R, Cubric-Curik V, Schwend K, Achmann R, et al. (2006). Genetic characterization and breed assignment in Austrian sheep breeds using microsatellite marker information. J. Anim. Breed. Genet. 123: 265-271.

Blackburn HD, Paiva SR, Wildeus S, Getz W, et al. (2011). Genetic structure and diversity among sheep breeds in the United States: identification of the major gene pools. J. Anim. Sci. 89: 2336-2348.

Calvo JH, Alvarez-Rodriguez J, Marcos-Carcavilla A, Serrano M, et al. (2011). Genetic diversity in the Churra tensina and Churra lebrijana endangered Spanish sheep breeds and relationship with other Churra group breeds and Spanish mouflon. Small Rumin. Res. 95: 34-39.

Crispim BA, Silva DBS, Banari AL, Seno LO, et al. (2012). Discriminação alélica em ovinos naturalizados do Pantanal Sul-Matogrossense por meio de marcadores microssatélites. J. Selva Andina Res. Soc. 3: 3-13.

Earl DA and vonHoldt BM (2012). STRUCTURE HARVESTER: a website and program for visualizing STRUCTURE output and implementing the Evanno method. Conserv. Genet. Resour. 4: 359-361.

Evanno G, Regnaut S and Goudet J (2005). Detecting the number of clusters of individuals using the software STRUCTURE: a simulation study. Mol. Ecol. 14: 2611-2620.

Gomes WSG, Araújo AR, Caetano AR, Martins CF, et al. (2007). Origem e Diversidade Genética da Ovelha Crioula do Pantanal, Brasil. In: Simposio de Recursos Genéticos para América Latina y El Caribe. Universidad Autónoma Chapingo, Chapingo, México.

Gornas N, Weimann C, El Hussien A and Erhardt G (2011). Genetic characterization of local Sudanese sheep breeds using DNA markers. Small Rumin. Res. 95: 27-33.

Goudet J (2002). FSTAT: A Program to Estimate and Test Gene Diversities and Fixation Indices (Version 2.9.3.2). Available at [http://www2.unil.ch/popgen/softwares/fstat.htm]. Accessed May 10, 2013.

Kalinowski ST, Taper ML and Marshall TC (2007). Revising how the computer program CERVUS accommodates genotyping error increases success in paternity assignment. Mol. Ecol. 16: 1099-1106.

Lasagna E, Bianchi M, Ceccobelli S, Landi V, et al. (2011). Genetic relationships and population structure in three Italian Merino-derived sheep breeds. Small Rumin. Res. 96: 111-119.

McManus C, Paiva SR and Araújo RO (2010). Genetics and breeding of sheep in Brazil. Rev. Bras. Zootec. 39: 236-246.

Paiva SR, Faco O, Faria DA, Lacerda T, et al. (2011a). Molecular and pedigree analysis applied to conservation of animal genetic resources: the case of Brazilian Somali hair sheep. Trop. Anim. Health Prod. 43: 1449-1457.

Paiva SR, Mariante AS and Blackburn HD (2011b). Combining US and Brazilian microsatellite data for a meta-analysis of sheep (Ovis aries) breed diversity: facilitating the FAO Global Plan of Action for Conserving Animal Genetic Resources. J. Hered. 102: 697-704.

Pritchard JK, Stephens M and Donnelly P (2000). Inference of population structure using multilocus genotype data. Genetics 155: 945-959.

Regitano LCA and Coutinho LL (2001). Introdução à Análise de Marcadores Moleculares. Biologia Molecular Aplicada à Produção Animal. Embrapa, Brasília, 11-25.

Rosa AJM and Paiva SR (2009). Marcadores Moleculares e suas Aplicações em Estudos Populacionais de Espécies de Interesse Zootécnico. Planaltina, Embrapa Cerrados, Brasil.

Sambrook J, Fritsch EF and Maniatis T (1989). Molecular Cloning. A Laboratory Manual. 2nd ed. Cold Spring Harbor Laboratory Press, Cold Spring Harbor.

Schneider S, Roessli D and Excoffier L (2000). Arlequin Version 2000: A Software for Population Genetics Data Analysis. Genetics and Biometry Laboratory, University of Geneva, Geneva.

Souza CA, Paiva SR, McManus CM, Azevedo HC, et al. (2012). Genetic diversity and assessment of 23 microsatellite markers for parentage testing of Santa Ines hair sheep in Brazil. Genet. Mol. Res. 11: 1217-1229.

Tolone M, Mastrangelo S, Rosa AJM and Portolano B (2012). Genetic diversity and population structure of Sicilian sheep breeds using microsatellite markers. Small Rumin. Res. 102: 18-25.

Vargas Junior FM, Longo ML, Seno LO, Pinto GS, et al. (2011). Potencial produtivo de um grupamento genético de ovinos nativos Sulmatogrossenses. Pubvet 30: 1197.

Yeh FC (2000). Population Genetics. In: Forest Conservation Genetics: Principles and Practice (Young A, Boshier D and Boyle T, eds.). CSIRO Publishing, Collingwood, 21-37. 